Jurnal Bimbingan dan Konseling Ar-Rahman
Volume 7, Nomor 1, Tahun 2021
Tersedia Online: http://ojs.uniska.ac.id/index.php/BKA
e-ISSN 2477-6300

\title{
HUBUNGAN ANTARA SELF CONTROL DAN SELF ESTEEM DENGAN PERILAKU MENYONTEK PADA PESERTA DIDIK DI SEKOLAH MENENGAH PERTAMA DI YOGYAKARTA
}

\author{
Eko Perianto \\ Universitas PGRI Yogyakarta \\ ekoperianto@upy.ac.id
}

\begin{abstract}
ABSTRAK
Penelitian ini bertujuan untuk mengetahui apakah ada hubungan negatif antara kontrol diri terhadap perilaku mencontek dan harga diri terhadap perilaku mencontek pada peserta didik Sekolah Menengah Pertama di Yogyakarta. Pengambilan sampel dalam penelitian ini menggunakan Stratified Random Sampling. Sampel dalam penelitian ini yaitu $25 \%$ dari jumlah populasi yaitu 64 orang. Teknik dalam pengambilan data dengan menggunakan skala kontrol diri, skala harga diri dan skala perilaku mencontek. Teknik analisis dalam penelitian ini dengan menggunakan Analisis korelasi. Hasil penelitian menunjukkan bahwa (1) Pada hipotesis Pertama menunjukkan bahwa antara kontrol diri (self control) dengan perilaku mencontek (cheating behavior) dinyatakan signifikan dengan nilai $r=-0,407(p<0,05)$. Menunjukkan bahwa ada hubungan negatif yang signifikan antara kontrol diri (self control) dengan perilaku mencontek (cheating behavior). (2) Pada hipotesis kedua menunjukkan bahwa antara harga diri (self esteem) dengan perilaku mencontek (cheating behavior) dinyatakan signifikan dengan nilai $\mathrm{r}=$ $0,541(\mathrm{p}<0,05)$. Menunjukkan bahwa ada hubungan negatif yang signifikan antara harga diri (self esteem) dengan perilaku mencontek (cheating behavior). Bagi Peneliti selanjutnya dapat mengembangkan lebih jauh berkaitan dengan menguji hipotesis dengan variabel perilaku mencontek terhadap variabel lainnya. Dimana masih ada faktor-faktor lain yang dapat mempengaruhinya sehingga dapat dilakukan penelitian kembali secara mendalam oleh para peneliti selanjutnya.
\end{abstract}

Kata Kunci: Kontrol Diri; Harga Diri; Perilaku Menyontek; Peserta Didik

\section{ABSTRACT}

This study aims to determine whether there is a negative relationship between self-control on cheating behavior and self-esteem on cheating behavior among junior high school students in Yogyakarta. Sampling in this study using a Stratified Random Samplin. The sample in this study is 25\% of the total population, namely 64 people. Techniques in collecting data using a scale of self-control, a scale of selfesteem and a scale of cheating behavior. The analysis technique in this research is using correlation analysis. The results showed that (1) The first hypothesis shows that between self-control and cheating behavior is significant with a value of $r=-0.407(p<0.05)$. This shows that there is a significant negative relationship between self-control and cheating behavior. (2) The second hypothesis shows that selfesteem and cheating behavior are significant with a value of $r=-0.541 \quad(p<0.05)$. It shows that there is a significant negative relationship between self-esteem and cheating behavior. For further researchers, they can develop further with regard to testing hypotheses with the variable cheating behavior on other variables. Where there are other factors that can influence it so that further research can be carried out in depth by further researchers.

Keywords: Self-Control; Self-Esteem; Cheating Behavior; Student

Dipublikasikan Oleh :

UPT Publikasi dan Pengelolaan Jurnal

Universitas Islam Kalimantan Muhammad Arsyad Al-Banjari Banjarmasin 
Eko Perianto

Jurnal Bimbingan dan Konseling Ar-Rahman

Volume 7, Nomor 1, Tahun 2021

e-ISSN 2477-6300

\section{PENDAHULUAN}

Mencontek adalah salah satu fenomena dalam dunia pendidikan yang sering dan bahkan selalu muncul menyertai aktivitas proses belajar mengajar sehari-hari, namun ada alasan mengapa orang melakukan mencontek pada saat ujian seperti halnya berkeinginan untuk mendapatkan keuntungan tersendiri dalam hal ini adalah nilai yang bagus. Iklim sekolah juga akan berbengaruh terhadap perilaku peserta didik untuk melakukan tindakan mencontek. Lingkungan atau iklim sekolah yang kompetitif dan terfokus pada prestasi akan menekan siswa untuk mendapatkan hasil yang baik, sehingga terjadi persaingan yang tidak sehat diantara siswa dan memungkinkan munculnya perilaku menyontek (Dwitantyanov, 2012).

Perilaku mencontek merupakan perilaku yang kompleks, meskipun bukan merupakan perilaku yang sifatnya klinis. Perilaku mencontek dapat dipengaruhi oleh banyak faktor sehingga mendorong peserta didik melakukan hal tersebut. Faktor-faktor tersebut diantaranya kontrol diri dan keyakinan diri seseorang. Seperti hal yang dikemukakan oleh Muslifah (2013) mengatakan bahwa intensi perilaku menyontek dipengaruhi oleh beberapa faktor meliputi orang lain, keyakinan diri, kontrol diri, dan motivasi.

Problem mencontek sudah menjadi menjadi hal yang biasa bagi peserta didik di sekolah dan sudah hilangnya kejujuran. Seperti halnya yang diungkapkan oleh Nurcholish (2011), bahwa kecurangan di sekolah merupakan contoh kecil sudah matinya kejujuran di lingkungan pendidikan khususnya di sekolah.

Selain dari matinya kejujuran yang harus dibangun oleh pendidik kepada peserta didik, pendidik seyogyanya menanamkan rasa kepercayaan diri pada peserta didik. Penanaman rasa percaya diri kepada peserta didik dipandang sangat perlu karena akan berdampak pada diri peserta didik itu sendiri. Seperti halnya yang dikemukakan oleh mantan menteri pendidikan nasioanl Malik Fajar (2011), bahwa kasus mencontek merupakan wujud dari hilangnya rasa kepercayaan diri pada peserta didik dan pendidik. Ini menunjukkan bahwa problem mencontek tidak hanya terjadi pada sekolah menengah ke atas, namun juga terjadi pada sekolah dasar. Secara keseluruhan bahwa problem mencontek dapat terjadi pada sekolah.

Peserta didik yang merasa bahwa dirinya kurang menguasai bahan yang diujikan akan mengandalkan mencontek untuk mendapatkan nilai yang baik. Mencontek bisa dikatakan wajar bila dilakukan hanya sekali dua kali karena alasan tertentu, akan tetapi bila dilakukan secara terus menerus di saat mengikuti tes atau ujian menjadi sebuah ketidakwajaran. Dikatakan tidak wajar karena sudah mengandalkan menyontek untuk mendapatkan nilai yang bagus. Hal tersebut secara tidak langsung akan berpaengaruh pada bagaiaman seseorang melakukan kontrol diri terhadap dirinya. Kontrol diri yang merupakan salah satu faktor seseorang memiliki perilaku mencontek. Seperti halnya yang dikemukkan oleh Chaplin (2011) berkaitan dengan kontrol diri adalah kemampuan untuk membimbing tingkah laku sendiri dalam artian kemampuan seseorang untuk menekan atau merintangi impuls-impuls atau tingkah laku impulsif.

Penelitian ini melibatkan tiga variabel yaitu perilaku mencontek, kontrol diri dan harga diri. Dipilihnya dua variabel bebas yaitu kontrol diri dan harga diri dengan alasan bahwa kedua variabel tersebut memiliki keterkaitan dengan perilaku mencontek. Artinya seorang individu yang tidak memiliki kontrol diri yang baik akan memiliki perilaku mencontek, (Muslifah, 2013). Ketika berpeluang untuk bertindak menyimpang orang-orang yang kurang kontrol diri tidak akan mampu menahan godaan. Mencontek merupakan salah satu perilaku menyimpang yang di luar batas kewajaran, dimana perilaku ini adalah perilaku curang untuk mendapatkan sesuatu dengan cara yang tidak baik. Jika perilaku ini dibiarkan saja tanpa adanya solusi untuk mencegah dan memberhentikannya, maka perilaku ini akan terus dijumpai dan dilakukan oleh para peserta didik.

Selain daripada kontrol diri perilaku mencontek juga dapat disebabkan oleh kurangnya harga diri. Orang yang memiliki harga diri yang tinggi tau positif memiliki keyakinan akan kemampuan yang dimilikinya dan merasa dirinya berharga, sedangkan mereka yang memiliki harga diri yang rendah atau negatif akan merasa 
dirinya lemah dan tidak berdaya dalam melakukan sesuatu (Irawati dan Hajat, 2012).

Kontrol diri atau self kontrol merupakan suatu kecakapan individu dalam kepekaan membaca situasi diri dan lingkungannya. Dapat juga diartikan sebagai kemampuan untuk mengontrol dan mengelola faktor-faktor perilaku sesuai dengan situasi dan kondisi untuk menampilkan diri dalam melakukan sosialisasi. Banyak orang mencampuradukkan sikap mengontrol diri dengan sikap kaku, keras, tegang atau terhambat. Sikap ini tentunya sangat berbeda, karena orang yang bisa mengkontrol dirinya, sangat mampu untuk bersikap fleksibel. Sementara yang kaku dan terhambat, bisa saja tampil terkontrol, tetapi mudah patah, dan bahkan bisa meledak, lepas kontrol. Orang yang memiliki kontrol diri yang baik akan tampil percaya diri di pergaulan dan pekerjaan, berintegritas dan yang paling penting, mempunyai daya adaptasi terhadap perubahan. Orang dengan kontrol diri yang baik akan mudah menjadi orang yang inovatif, bahkan dalam pergaulan bisa mengembangkan sifat empatinya.

Perilaku mencontek salah satu perilaku menyimpang yang dapat dilakukan oleh seseorang pada dunia pendidikan. Dimana perilaku tersebut dilakukan untuk mendapatkan sesuatu akan tetapi dengan menggunakan hal-hal yang sifatnya negatif. Bila dihubungkan dengan kontrol diri maka perilaku mencontek ini merupakan hal yang negatif. Perilaku mencontek merupakan perilaku yang menyimpang. Kontrol diri yang kurang baik akan mempengaruhi bagaimana peserta didik berperilaku dan pada akhirnya akan merugikan diri sendiri. Hingga pada akhirnya dapat disimpulkan bahwa orang individu yang memiliki perilaku mencontek salah satu penyebabnya adalah kurangnya kontrol diri.

Self esteem yang artinya harga diri adalah penilaian seseorang tentang diri sendiri yang menunjukkan seberapa besar merasa mampu, berhasil dan berharga. Seperti halnya dikemukakan oleh Santrock (2012) harga diri merupakan evaluasi individu terhadap dirinya sendiri secara positif atau negatif. Evaluasi ini memperlihatkan bagaimana individu menilai sendiri dan diakui atau tidaknya kemampuan dan keberhasilan yang diperolehnya. Penilaian tersebut terlihat dari penghargaan terhadap keberadaan dan keberartian dirinya.

Selanjutnya Coopersmith (dalam Sumarsongko,2015) mendefinisikan harga diri sebagai penilaian diri yang dilakukan oleh seorang individu dan biasanya berkaitan dengan dirinya sendiri. Penilaian tersebut mencerminkan sikap penerimaan dan penolakan serta mennjukan seberapa jauh individu percaya bahwa dirinya mampu, penting, berhasil dan berharga.

Individu yang memiliki harga diri yang positif akan menerima dan menghargai dirinya sendiri apa adanya. Penghargaan diri yang tinggi akan mengakibatkan individu menjadi orang yang mempunyai rasa percaya diri yang tinggi, selain itu individu akan merasa lebih yakin dengan kemampuan yang dimilikinya dan akan merasa berguna bagi lingkungan sekitarnya. Harga diri yang rendah dapat diintervensi agar dapat meningkat dengan tujuan tertentu. Seperti halnya yang dikemukakan oleh Sharma dan Agarwala (2015) dalam artikelnya. Menuliskan bahwa Intervensi perilaku efektif dalam meningkatkan harga diri individu yang memiliki harga diri rendah.

Penghargaan terhadap diri setiap orang akan berbeda dengan yang lainnya, tergantung pada aspek apa yang mempengaruhinya. Jenis kelamin atau gender merupakan salah satu asepek yang dapat mempengaruhi apakah seseorang itu tinggi atau rendah dalam menghargai dirinya. Salah satu perkembangan psikologis yang dialami oleh remaja adalah perkembangan sosioemosi yang salah satunya adalah harga diri, yang merupakan keseluruhan cara yang digunakan untuk mengevaluasi diri sendiri, dimana harga diri merupakan perbandingan antara diri yang ideal dengan diri yang sebenarnya (Santrock, 2012).

Peserta didik yang memiliki penghargaan terhadap dirinya dengan meyakini akan kemampuan yang dimiliki tentunya akan melakukan hal-hal yang positif. Hal-hal positif tersebut salah satunya adalah dengan tidak melakukan tindakan mencontek pada saat mengikuti ujian di sekolah. Percaya diri yang dimiliki oleh peserta didik merupakan implikasi dari harga diri yang dimilikinya. 
Eko Perianto

Jurnal Bimbingan dan Konseling Ar-Rahman

Volume 7, Nomor 1, Tahun 2021

e-ISSN 2477-6300

Penelitian lain yang berkaitan dengan kontrol diri yang dilakukan oleh Nafeesa (2017) menuliskan bahwa Berdasarkan analisis data, diperoleh hasil terdapat hubungan negatif antara kontrol diri dengan perilaku menyontek. Hasil ini dibuktikan dengan koefisien korelasi, dimana rxy $=-0.222 ; \mathrm{p}=0.002<0.05$. Nilai koefisien determinasi ( $\mathrm{R}$ square) penelitian dengan nilai sebesar 0.049. Dapat diartikan bahwa variabel kontrol diri mempengaruhi perilaku menyontek sebesar $4.9 \%$. artinya bahwa ada hubungan yang negative antara control diri dengan perilaku mencontek siswa. Semakin tinggi control diri siswa maka semakin rencah perilaku mencontek yang dimiliki oleh siswa.

Hasil penelitian (Wahyuningrum dan Palila, 2014) menyebutkan Hasil penelitian menunjukkan bahwa hasi uji uji korelasi antara harga diri terhadap perilaku menyontek sebesar 0,254 dengan $\mathrm{p}=0,004(\mathrm{p}<0,05)$. Besar sumbangan efektif harga diri terhadap perilaku menyontek sebesar $6,5 \%(\mathrm{R} 2=0,065)$, sedangkan sisanya $93,5 \%$ merupakan faktor lain yang diduga turut berpengaruh dalam perilaku menyontek. Penelitian lain yang dilakukan oleh Devi Kusrieni, (2014) menunjukkan bahwa efikasi diri terhadap perilaku mencontek pada siswa kelas $\mathrm{X}$ SMA Negeri 4 Yogyakarta memiiki peran sebesar $21,3 \%$ dan sisanya $78,7 \%$ perilaku mencontek disebabkan oleh variabel lain di luar efikasi diri seperti prokrastinasi, tekanan dari teman sebaya, dan tekanan dari orang tua.

Selanjutnya penelitian yang di lakukan oleh Ratna, (2018) tentang harga diri menunjukkan bahwa terdapat hubungan positif dan signifikan antara harga diri dan interaksi teman sebaya terhadap perundungan dengan nilai $\mathrm{F}=6.705, \mathrm{R} 2=0.125$, dan $\mathrm{p}=0.002$ artinya semakin tinggi harga diri dan interaksi teman sebaya yang dimiliki siswa maka akan semakin tinggi perundungan yang dilakukan siswa SMK Negeri 7 Samarinda, yang berarti ketika siswa memiliki pandangan terhadap dirinya sendiri baik bersifat positif ataupun negatif serta siswa melakukan interaksi terhadap siswa lain ataupun kelompok siswa lainnya yang akan mempengaruhi perilakunya maka siswa tersebut bisa saja akan melakukan perilaku perundungan kepada siswa lain yang disebakan dari pandangan terhadap diri sendiri maupun akibat dari interaksi teman sebayanya.

\section{METODE}

Penelitian ini merupakan penelitian kuantitatif dan bertujuan menguji apakah ada hubungan antara variabel pertama dengan variabel ketiga dan variabel kedua dengan variabel ketiga. Variabel dalam penelitian ini adalah Kontrol Diri (Self Control) dan Harga diri (Self Esteem) sebagai variabel bebas Perilaku Mencontek (Cheating Behavior). Apabila pada variabel kontrol diri dengan perilaku mencotek terdapat hubungan maka diartikan bahwa semakin tinggi kontrol diri maka semakin rendah perilaku mencontek. Sebaliknya apabila kontrol diri rencah pada perilaku menconteknya tinggi. Pada variabel harga diri dan perilaku mencontek diartikan bahwa apabila harga diri tinggi maka perilaku mencontek rendah. Sebaliknya apabila harga diri rencah maka perlaku menconteknya tinggi.

Penelitian ini menggunakan penskalaan model Likert yang dimodifikasi yaitu meniadakan kategori jawaban tengah atau netral untuk menghilangkan central tendency effect yang sering muncul dalam skala lima tingkat. Alasan dalam penggunaan skala dalam penenlitian ini melihat sejauhmana sikap yang dimiliki oleh seorang responden.

Pengumpulan data dalam penelitian ini dengan menggunakan skala yang dibagi menjadi tiga skala sesuai dengan variabel dalam penelitian ini yaitu, (1) Skala Perilaku Mencontek (Cheating Behavior), (2) Skala Kontrol Diri (Self Control), (3) Skala Harga diri (Self Esteem). Skala penelitian ini dikembangkan oleh peneliti sendiri dan sudah melalui uji validitas dan reliabilitas dan terdiri dari dua bagian yang harus di isi oleh subyek penelitian, (Azwar, 2014).

Populasi dalam penelitian ini berjumlah 257 orang, Jika jumlahnya subyeknya besar dapat diambil antara $10-15 \%$ atau $20-25 \%$ atau lebih. (Arikunto, 2017). Penelitian ini menggunakan 25\% dari jumlah populasi yang dijadikan sebagai subyek peneltian sehingga jumlah sampel yaitu 64 dari jumlah populasi.

Uji normalitas berrrtujuan untuk menentukan apakah popluasi dalam penelitian mempunyai sebaran normal atau tidak. 
Perhitungan uji normalitas menggunakan bantuan program computer SPSS for Windows Release 16.0 pada Nonparametric One-Sample Kolmogorov-Smirnov (K-S) Test (Terlampir). Kriteria pengambilan keputusan adalah populasi mempunyai sebaran data normal apabila probabilitasnya (Asymp. Sig. 2 - tailed) $\geq 0,05$. Semua variabel (Asymp. Sig. 2 _tailed) $\geq 0,05$, sehingga dapat di simpulkan bahwa data diambil dari populasi berdistribusi normal.

Analisis data yang digunakan dalam penelitian ini dengan menggunakan menggunakan uji korelasi product moment. Proses analisis dilakukan dengan menggunakan bantuan program komputer SPSS versi 16.0.

\section{HASIL DAN PEMBAHASAN}

Uji Korelasi dilakukan untuk menguji hipotesis pertama dan kedua terhadap variabel terikat dari penelitian ini. Adapun hasil uji korelasi Product Moment yang terdiri dua variabel bebas yaitu kontrol diri (self control) dan harga diri (self esteem) terhadap variabel terikat yaitu perilaku mencontek (cheating behavior).

Selanjutnya akan digambarkan melalui tabel berkaitan dengan masing-masing variabel hasil analisis masing-masing variabel dalam penelitian ini.

Tabel 1. Kategorisasi Variabel Kontrol Diri

\begin{tabular}{lclc}
\hline \multicolumn{1}{c}{ Rentang Skor } & Frekuensi & \multicolumn{1}{c}{ Kategorisasi } & Persentase (\%) \\
\hline $\mathbf{7 1 , 4}<\mathbf{X}$ & 2 & Sangat Tinggi & 3,12 \\
$\mathbf{5 8 , 8}<\mathbf{X} \leq \mathbf{7 1 , 4}$ & 45 & Tinggi & 70,32 \\
$\mathbf{4 6 , 2}<\mathbf{X} \leq \mathbf{5 8 , 8}$ & 17 & Sedang & 26,56 \\
$\mathbf{3 3 , 6}<\mathbf{X} \leq \mathbf{4 6 , 2}$ & - & Rendah & - \\
$\mathbf{X} \leq \mathbf{3 3 , 6}$ & - & Sangat Rendah & - \\
\hline
\end{tabular}

Tabel 2. Kategorisasi Variabel Harga Diri

\begin{tabular}{lclc}
\hline \multicolumn{1}{c}{ Rentang Skor } & Frekuensi & \multicolumn{1}{c}{ Kategorisasi } & Persentase (\%) \\
\hline $\mathbf{1 1 2 , 2}<\mathbf{X}$ & 4 & Sangat Tinggi & 6,25 \\
$\mathbf{9 2 , 4}<\mathbf{X} \leq \mathbf{1 1 2 , 2}$ & 56 & Tinggi & 87,5 \\
$\mathbf{7 2 , 6}<\mathbf{X} \leq \mathbf{9 2 , 4}$ & 4 & Sedang & 6,25 \\
$\mathbf{5 2 , 8}<\mathbf{X} \leq \mathbf{7 2 , 6}$ & - & Rendah & - \\
$\mathbf{X} \leq \mathbf{5 2 , 8}$ & - & Sangat Rendah & - \\
\hline
\end{tabular}

Tabel 3. Kategorisasi Variabel Perilaku Mencontek

\begin{tabular}{lclc}
\hline \multicolumn{1}{c}{ Rentang Skor } & Frekuensi & \multicolumn{1}{c}{ Kategorisasi } & Persentase (\%) \\
\hline $\mathbf{1 1 5 , 6}<\mathbf{X}$ & - & Sangat Tinggi & - \\
$\mathbf{9 5 , 2}<\mathbf{X} \leq \mathbf{1 1 5 , 6}$ & 1 & Tinggi & 1,57 \\
$\mathbf{7 4 , 8}<\mathbf{X} \leq \mathbf{9 5 , 2}$ & 58 & Sedang & 90,62 \\
$\mathbf{5 4 , 4}<\mathbf{X} \leq \mathbf{7 4 , 8}$ & 5 & Rendah & 7,81 \\
$\mathbf{X} \leq \mathbf{5 4 , 4}$ & - & Sangat Rendah & - \\
\hline
\end{tabular}

Selanjutnya akan dijelaskan secara singkat berkaitan dengan hasil analsisi tabel masing-masing variabel tersebut sebagai berikut:

Pada tabel kategorisasi variabel kontrol diri diatas menunjukkan data ordinal yang menjelaskan tentang hasil kategorisasi pada variabel kontrol diri (self control). Dari tabel diatas menunjukkan bahwa sebagian besar subyek berada dalam kategori tinggi, yaitu sebesar 70,32 $\%$ dengan jumlah subyek 45 orang.

Dilihat dari perbandingan rerata hipotetik dan empirik diperoleh hasil bahwa rerata empirik lebih tinggi bila dibandingkan rerata hipotetik $(61,53>52,5)$, sehingga dapat diartikan bahwa harga diri pada subyek penelitian cenderung tinggi. 
Penjelasan dari tabel juga dapat menggambarkan bahwa peserta didik pada Sekolah Menengah Pertama di Yogyakarta memiliki kontrol diri yang tinggi. Ini dapat dilihat dari kategori yang diperoleh, yaitu sebesar 70,32 $\%$ dengan jumlah subyek 45 orang. Artinya penelitian ini pada variabel kontrol diri subyek penelitian menunjukkan kontrol diri yang dimiliki tinggi. Kontrol diri yang cenderung tinggi pada tabel tersebut menunjukkan bahwa data subyek pada variabel ini normal dengan menunjukkan rerata empirik lebih tinggi bila dibandingkan rerata hipotetik. Data tersebut menunjukkan bahwa data yang ada dapat dijadikan data penelitian sebagai variabel bebas bagi variabel terikat dalam penelitian ini.

Pada tabel kategorisasi variabel harga diri menunjukkan data ordinal yang menjelaskan tentang hasil kategorisasi pada variabel harga diri (self esteem). Dari tabel diatas menunjukkan bahwa sebagian besar subyek berada dalam kategori tinggi, yaitu sebesar $87,5 \%$ dengan jumlah subyek 56 orang.

Dilihat dari perbandingan rerata hipotetik dan empirik diperoleh hasil bahwa rerata empirik lebih tinggi bila dibandingkan rerata hipotetik $(101,44>82,5)$, sehingga dapat diartikan bahwa harga diri pada subyek penelitian cenderung tinggi.

Penjelasan dari tabel juga dapat menggambarkan bahwa peserta didik pada Sekolah Menengah Pertama di Yogyakarta memiliki harga diri yang tinggi. Ini dapat dilihat dari kategori yang dilakukan, yaitu sebesar 87,5\% dengan jumlah subyek 56 orang. Artinya penelitian ini pada variabel harga diri subyek penelitian menunjukkan harga diri yang dimiliki tinggi. Harga diri yang cenderung tinggi pada tabel tersebut menunjukkan bahwa data subyek pada variabel ini normal dengan menunjukkan rerata empirik lebih tinggi bila dibandingkan rerata hipotetik. Data tersebut menunjukkan bahwa data yang ada dapat dijadikan data penelitian sebagai variabel bebas bagi variabel terikat dalam penelitian ini.

Pada tabel kategorisasi variabel perilaku mencontek menunjukkan data ordinal yang menjelaskan tentang hasil kategorisasi pada variabel Perilaku Mencontek (Cheating Behavior) dari tabel diatas menunjukkan bahwa sebagian besar subyek berada dalam kategori sedang, yaitu sebesar 90,62\% dengan jumlah subyek 58 orang. Pada kategori tinggi terdapat satu orang menunjukkan bahwa hanya 1,57 persen subyek yang dikatakan tidak memiliki perilaku mencontek.

Dilihat dari perbandingan rerata hipotetik dan empirik diperoleh hasil bahwa rerata empirik lebih rendah bila dibandingkan rerata hipotetik $(83,16<85)$, sehingga dapat diartikan bahwa perilaku mencontek pada subyek penelitian cenderung rendah. Perilaku mencontek yang cenderung rendah akan menunjukkan bahwa perilaku mencontek masih dimiliki oleh peserta didik.

Penjelasan dari tabel di atas juga dapat menggambarkan bahwa peserta didik pada Sekolah Menengah Pertama di Yogyakarta memiliki perilaku mencontek sedang. Ini dapat dilihat dari kategori yang dilakukan sebesar 90,62 $\%$ dengan jumlah subyek 58 orang. Artinya penelitian ini pada variabel perilaku mencontek menunjukkan bahwa perilaku mencontek masih dimiliki oleh peserta didik.

Dari hasil analisis yang dilakukan dapat dilihat bahwa korelasi antara kontrol diri (self control) dengan perilaku mencontek (cheating behavior) dinyatakan signifikan dengan nilai $\mathrm{r}=$ $0,407(\mathrm{p}<0,05)$. Tanda negatif pada nilai $\mathrm{r}$ adalah menunjukkan arah korelasi kedua variabel, Hal ini menunjukkan bahwa ada hubungan negatif yang signifikan antara kontrol diri (self control) dengan perilaku mencontek (cheating behavior). Artinya semakin tinggi kontrol diri yang dimiliki oleh peserta didik, maka semakin rendah perilaku mencontek yang dimiliki. Berdasarkan hasil analisis diperoleh nilai $\mathrm{R}^{2}$ sebesar 0,165 nilai tersebut menunjukkan sumbangan efektif variabel kontrol diri (self control) terhadap variabel perilaku mencontek (cheating behavior) sebesar $16,5 \%$.

Korelasi antara harga diri (self esteem) dengan perilaku mencontek (cheating behavior) dinyatakan signifikan dengan nilai $r=-0,541$ $(\mathrm{p}<0,05)$. Tanda negatif pada nilai $\mathrm{r}$ adalah menunjukkan arah korelasi kedua variabel, hal ini 
menunjukkan bahwa ada hubungan negatif yang signifikan antara harga diri (self esteem) dengan perilaku mencontek (cheating behavior). Artinya semakin tinggi harga diri peserta didik, maka semakin rendah perilaku mencontek yang dimiliki. Berdasarkan hasil analisis diperoleh nilai $\mathrm{R}^{2}$ sebesar 0,292 nilai tersebut menFunjukkan sumbangan efektif harga diri (self esteem) terhadap variabel perilaku mencontek (cheating behavior) sebesar 29,2\%.

Pengujian hipotesis Pertama, ada hubungan negatif antara kontrol diri (self control) dengan perilaku mencontek (cheating behavior) pada peserta didik di Sekolah Menengah Pertama di Yogyakarta. Artinya, semakin tinggi kontrol diri yang dimiliki peserta didik, maka perilaku mencontek semakin rendah. Sebaliknya, semakin rendah kontrol diri peserta didik, maka tingkat perilaku menyontek semakin tinggi. Kedua, ada hubungan negatif antara harga diri (self esteem) dengan perilaku menyontek (cheating behavior) pada peserta didik di Sekolah Menengah Pertama di Yogyakarta. Artiya, semakin tinggi harga diri yang dimiliki peserta didik, maka perilaku mencontek semakin rendah. Sebaliknya, semakin rendah harga diri peserta didik maka tingkat perilaku mencontek semakin tinggi.

Hipotesis pertama menunjukkan bahwa antara kontrol diri (self control) dengan perilaku mencontek (cheating behavior) dinyatakan signifikan dengan nilai $\mathrm{r}=-0,407 \quad(\mathrm{p}<0,05)$. Menunjukkan bahwa ada hubungan negatif yang signifikan antara kontrol diri (self control) dengan perilaku mencontek (cheating behavior). Artinya semakin tinggi nilai kontrol diri (self control), maka semakin rendah perilaku mencontek (cheating behavior). Ini sejalan dengan apa yang dikemukakan oleh Gottfredson \& Hirschi (Bolin, 2004) bahwa salah satu sebab dari perilaku mencontek (cheating behavior) dapat disebabkan oleh kontrol diri yang rendah. Juga seperti halnya hasil penelitian oleh (Nafeesa, 2017) menuliskan bahwa Berdasarkan hubungan negatif antara kontrol diri dengan perilaku menyontek. Hasil ini dibuktikan dengan koefisien korelasi, dimana rxy $=-0.222 ; \mathrm{p}=0.002<0.05$. Nilai koefisien determinasi ( $\mathrm{R}$ square) penelitian dengan nilai sebesar 0.049. Dapat diartikan bahwa variabel kontrol diri mempengaruhi perilaku menyontek sebesar 4.9\%.Dengan demikian bahwa hasil analisis penelitian ini dapat dikuatkan oleh hasil penelitian sebelumnya.

Berdasarkan hasil analisis diperoleh nilai $\mathrm{R}^{2}$ sebesar 0,165 nilai tersebut menunjukkan sumbangan efektif variabel kontrol diri (self control) terhadap variabel perilaku mencontek (cheating behavior) sebesar 16,5\%.

Hipotesis kedua menunjukkan bahwa antara harga diri (self esteem) dengan perilaku mencontek (cheating behavior) dinyatakan signifikan dengan nilai $r=-0,541(\mathrm{p}<0,05)$. Menunjukkan bahwa ada hubungan negatif yang signifikan antara harga diri (self esteem) dengan perilaku mencontek (cheating behavior). Artinya semakin tinggi nilai harga diri (self esteem) maka semakin meningkat perilaku mencontek (cheating behavior). Sesuai pendapat Bower (Donald L. McCabe, 2001), mengemukakan bahwa salah satu faktor yang menyebabkan individu memiliki perilaku mencontek adalah seberapa rendah tingginya harga diri yang dimiliki oleh individu.

Berdasarkan hasil analisis diperoleh nilai $\mathrm{R}^{2}$ sebesar 0,292 nilai tersebut menunjukkan sumbangan efektif harga diri (self esteem) terhadap variabel perilaku mencontek (cheating behavior) sebesar 29,2 \%. Selanjutnya akan ditampilkan tabel hasil dari korelasi antara variabel Kontrol Diri (Self Control) dan Harga diri (Self Esteem) terhadap Perilaku Mencontek (Cheating Behavior).

Pada tabel hasil korelasi menunjukkan bahwa hipotesis pertama yaitu kontrol diri (self control) terhadap perilaku mencontek (cheating behavior) terbukti signifikan secara negatif. Artinya bahwa semakin tinggi kontrol diri peserta didik maka semakin rendah perilaku mencontek perserta didik di Sekolah Menengah Pertama di Yogyakarta. Sebaliknya apabila kontrol diri rendah pada perilaku menconteknya tinggi. Seperti hal yang dikemukakan oleh Muslifah (2013) mengatakan bahwa intensi perilaku menyontek dipengaruhi oleh beberapa faktor meliputi orang lain, keyakinan diri, kontrol diri, dan motivasi.

Pada hipotesis harga diri (self esteem) terhadap perilaku mencontek (cheating behavior) juga terbukti signifikan secara negatif. Artinya bahwa semakin tingga harga diri peserta didik maka perilaku mencontek semakin rendah pada peserta didik di Sekolah Menengah Pertama di Yogyakarta. Sebaliknya apabila harga diri rencah maka perlaku menconteknya tinggi. Seperti halnya hasil penelitian (Wahyuningrum dan Palila, 
Eko Perianto

Jurnal Bimbingan dan Konseling Ar-Rahman

Volume 7, Nomor 1, Tahun 2021

e-ISSN 2477-6300

2014) bahwa harga diri dengan perilaku menyontek juga menunjukkan adanya hubungan negatif yang signifkan antara harga diri dengan perilaku menyontek. Semakin tinggi harga diri seseorang maka semakin rendah perilaku menconteknya. Begitu juga yang dituliskan oleh
Friyatmi (2011) bahwa faktor Faktor-faktor dominan penentu perilaku mencontek terbentuk menjadi tujuh faktor, yaitu faktor penguasaan materi, cara belajar, success story, konsep diri, motif personal, situasi, dan faktor sosial.

Tabel 4 Hasil korelasi antara variabel KD-PC dan HD -PC

\begin{tabular}{llrrr}
\hline & & KD_X1 & HD_X2 & \multicolumn{1}{c}{ PC_Y } \\
\hline KD_X1 & Pearson Correlation & 1 & 0.102 & $-0.407^{* *}$ \\
& Sig. (2-tailed) & & 0.423 & 0.001 \\
& N & 64 & 64 & 64 \\
\hline HD_X2 & Pearson Correlation & 0.102 & 1 & $-0.541^{* *}$ \\
& Sig. (2-tailed) & 0.423 & & 0.000 \\
& N & 64 & 64 & 64 \\
\hline PC_Y & Pearson Correlation & $-0.407^{* *}$ & $-0.541^{* *}$ & 1 \\
& Sig. (2-tailed) & 0.001 & 0.000 & \\
& N & 64 & 64 & 64 \\
\hline
\end{tabular}

**. Correlation is significant at the 0.01 level (2-tailed).

*KD : Kontrol Diri; HD : Harga Diri; PC : Perilaku Mencontek

\section{PENUTUP}

Pada penelitian ini hipotesis yang diajukan yaitu hipotesis pertama menunjukkan bahwa antara kontrol diri (self control) dengan perilaku mencontek (cheating behavior) dinyatakan signifikan dengan nilai $\mathrm{r}=-0,407 \quad(\mathrm{p}>0,05)$. Menunjukkan bahwa ada hubungan negatif yang signifikan antara kontrol diri (self control) dengan perilaku mencontek (cheating behavior). Artinya semakin tinggi kontrol diri (self control) maka semakin rendah perilaku mencontek (cheating behavior). Berdasarkan hasil analisis dapat diketahui sumbangan efektif variabel kontrol diri (self control) terhadap variabel perilaku mencontek (cheating behavior) yakni 16,5\%.

Pada hipotesis kedua menunjukkan bahwa antara harga diri (self esteem) dengan perilaku mencontek (cheating behavior) dinyatakan signifikan dengan nilai $r=-0,541(p>0,05)$. Menunjukkan bahwa ada hubungan negatif yang signifikan antara harga diri (self esteem) dengan perilaku mencontek (cheating behavior). Artinya semakin tinggi harga diri (self esteem) maka semakin rendah perilaku mencontek (cheating behavior). Berdasarkan hasil analisis dapat diketahui sumbangan efektif variabel harga diri (self esteem) terhadap variabel perilaku mencontek (cheating behavior) yakni 29,2\% .

Bagi Peneliti selanjutnya dapat mengembangkan lebih jauh berkaitan dengan menguji hipotesis dengan variabel perilaku mencontek terhadap variabel lainnya. Dimana masih ada faktor-faktor lain yang dapat mempengaruhinya sehingga dapat dilakukan penelitian kembali secara mendalam oleh para peneliti selanjutnya

\section{REFERENSI}

Arikunto, S. (2017). Pengembangan Instrumen Penelitian dan Penilaian Program. Yogyakarta: Pustaka Pelajar.

Azwar, S. (2014). Reliabilitas dan Validitas (edisi 4). Yogyakarta: Pustaka Pelajar.

Bolin, Aaron U. (2004). Self-Kontrol, Perceived Opportunitiy, and Attitudes as Predictors of Academic Dishonesty,The Journal of Psychology, 138(2), 101-114 
Chaplin. (2011). Kamus Lengap Psikologi. Jakarta: Rajawali Pers.

Devi Kusrieni. (2014). Hubungan Efikasi Diri dengan Perilaku Mencontek. Jurnal. PSIKOPEDAGOGIA, 3(2).

Fitiyatmi. (2011). Faktor-faktor Penentu Perilaku Mencontek di Kalangan Mahasiswa Fakultas Ekonomi UNP. Jurnal TINGKAP, VII (2).

Fajar M. (2011). Pendidik Harus Jujur dan Adil. Kedauatan Rakyat, 21 Juni 2011. Yogyakarta.

Irawati, N \& Hajat, N. (2012). Hubungan antara harga diri (self esteem) dengan prestasi belajar pada siswa SMKN 48 di Jakarta timur. Jurnal Econosains, 10, 193210.

McCabe, D.L., Trevino, L.K., Butterfield, K.D. (2001). Cheating On Academic Institution: A Decade Of Research. Ethic \& Behavior, 1(3).

Muslifah F. (2013). Hubungan antara Kontrol Diri dengan Intensi Perilaku Menyontek pada Siswa SMP Negeri 1 Prambanan. Jurnal Bimbingan dan Konseling, 3.

Nafeesa. (2017). Hubungan Kontrol Diri dengan Perilaku Menyontek pada Siswa YP Mts. Al-Azhar Medan. Jurnal Diversita, 3(1).

Nurcholish (2011). Hilangnya Kejujuran di Sekolah. Kedauatan Rakyat, 21 Juni 2011. Yogyakarta.

Ratna, (2018). Hubungan Harga Diri dan Interaksi Teman Sebaya Terhadap Perilaku Perundungan. Psikoborneo, 6(3).

Santrock, J.W. (2012). Life-Span Development (Perkembangan Masa Hidup Edisi 13 Jilid 1, Penerjemah: Widyasinta, B). Jakarta: Erlangga.

Sumarsongko, S. (2015). Hubungan Antara Harga Diri dengan Perilaku Prososial pada Satpam PT Danliris. Surakarta.

Sharma, S, Agarwala S. (2019). Self-Esteem and Collective Self-Esteem Among Adolescents: An Interventional Approach. Psychological Thought. 2193-7281.

Wahyuningrum dan Palila, (2014).Harga DIRI Dan iklim Sekolah Dengan Perilaku menyontek pada Siswa SMP Negeri 2 Sleman. Junral Psikologi Integratif, 2(2). 